\title{
Dry matter production and nitrogen utilization in cropping systems with grass, lucerne and maize. 2 . Nitrogen yield and utilization
}

\author{
J. H. J. Spiertz and L. Sibma \\ Centre for Agrobiological Research (CABO), P.O. Box 14, 6700 AA Wagenin- \\ gen, Netherlands
}

Received 11 April 1985; accepted 5 June 1985

Key words: forage production, grass, lucerne, maize, soil nitrogen, nitrogen fixation, nitrogen yield, nitrogen utilization, residual effects

\begin{abstract}
In a three-year experiment with various cropping systems of grass, lucerne and maize the nitrogen yield and the nitrogen use efficiency were studied. To compare the nitrogen economy of the various cropping systems the residual effects were also determined of preceding crops of grass, lucerne and maize on a following maize crop.

Nitrogen yields of grass and maize were about 450 and $200 \mathrm{~kg} \mathrm{ha}^{-1}$, respectively. Nitrogen yields of lucerne ranged from about 400 to $600 \mathrm{~kg} \mathrm{ha}^{-1}$ depending on crop age and weather conditions.

Nitrogen fixation rates of lucerne were assessed in 1982 with the difference method; estimates of nitrogen fixation ranged from 107 to $507 \mathrm{~kg} \mathrm{ha}^{-1}$ for high and no nitrogen fertilization, respectively.

The after-effects of 1-, 2- and 3-year crops of grass, lucerne and maize were measured on the dry matter and nitrogen yields of a test crop maize. Depending on the age of the preceding grass crop, annually supplied with $450 \mathrm{~kg} \mathrm{~N} \mathrm{ha}^{-1}$, the nitrogen after-effects ranged from 120 to $175 \mathrm{~kg} \mathrm{ha}^{-1}$. The after-effect of a previous cropping with lucerne was independent of the nitrogen dressing and ranged from 140 to 175 $\mathrm{kg} \mathrm{ha}^{-1}$. For comparison, it may be noticed that the after-effect of a preceding maize crop ranged from 90 to $110 \mathrm{~kg} \mathrm{ha}^{-1}$.

To study the effects of the cropping system on soil fertility and soil $\mathrm{N}$ losses the mineral soil $\mathrm{N}$ reserves were determined in spring and autumn.
\end{abstract}

\section{Introduction}

During the past decades forage production on dairy farms in north-west Europe has been mainly based on intensively managed permanent grassland with high amounts 


\section{J. H. J. SPIERTZ AND L. SIBMA}

of nitrogen fertilizer (van Burg et al., 1980). Balance sheet studies of nitrogen cycling in dairy farms show potentially high nitrogen losses with nitrogen fertilizer inputs of about $400 \mathrm{~kg} \mathrm{ha}^{-1}$ year $^{-1}$ (van der Meer, 1982).

The increasing prices of nitrogen fertilizer and the growing concern for side-effects on the environment of high nitrogen dressings give a new scope for studying the potential of forage legumes as a perennial crop or in crop rotation.

The role of legumes in forage production is mainly determined by their capacity to fix nitrogen from the air by the process of nitrogen fixation and their capacity to achieve a high protein yield.

The replacement of grass by lucerne within a cropping system may result in less use of nitrogen fertilizer and a high nitrogen use efficiency.

To study the yield potential of lucerne in comparison with grass and maize a field experiment was carried out in three successive years and the after-effects were assessed in a following maize crop. A previous paper (Sibma \& Spiertz, 1986) dealt with dry matter yield, growth pattern and crop characteristics. In the present paper data on nitrogen yield, nitrogen fixation and nitrogen use efficiency are presented and discussed. Besides the direct effects of nitrogen fertilizer and nitrogen fixation on the main crop, the after-effects on a following crop are also presented.

\section{Material and methods}

The lay-out of the field experiment and the treatments in the experiment with grass, lucerne and maize were described in our previous paper (Sibma \& Spiertz, 1986). The experiment was carried out in the years 1980 to 1983 at an experimental farm at Flevoland.

The cropping systems consisted of:

- G1, G2 and G3 for the cultivation of perennial ryegrass for one, two or three years, respectively

- L1, L2 and L3 for the cultivation of lucerne in the same way

- M1, M2 and M3 for the cultivation of maize with arable crops and a mixture of grass and lucerne.

The following test-crop in 1983, maize, was sown late, on 6 June. As a consequence, nitrogen uptake may have been reduced. In 1983 no $\mathrm{N}$ fertilizer was applicated to all treatments but one; the M1 treatment received four rates of nitrogen: 0 , 75,150 and $225 \mathrm{~kg} \mathrm{ha}^{-1}$.

In addition to the measurements already presented in the first paper, every year in spring and autumn mineral soil nitrogen contents were determined by sampling soil layers of $20 \mathrm{~cm}$ to a depth of $60 \mathrm{~cm}$. The most extensive sampling was carried out in the years 1982 and 1983.

\section{Results}

Nitrogen yields of grass, lucerne and maize

Nitrogen yields of the crops during three years are presented for grass dressed with $450 \mathrm{~kg} \mathrm{ha}^{-1}$ year $^{-1}$, unfertilized lucerne and maize dressed with $225 \mathrm{~kg} \mathrm{ha}^{-1}$ year $^{-1}$ 
Table 1. $\mathrm{N}$ yields per annum in $\mathrm{kg} \mathrm{ha}^{-1}$ and $\mathrm{N}$ content in $\mathrm{g} \mathrm{kg}^{-1}$ of 3-, 2- and 1 -year old grass, lucerne and maize in 1980,1981 and 1982.

\begin{tabular}{|c|c|c|c|c|c|c|}
\hline \multirow[t]{2}{*}{ Treatment } & \multicolumn{2}{|l|}{1980} & \multicolumn{2}{|l|}{1981} & \multicolumn{2}{|l|}{1982} \\
\hline & $\begin{array}{l}\mathrm{N} \text { content } \\
\mathrm{g} \mathrm{kg}^{-1}\end{array}$ & $\begin{array}{l}\text { N yield } \\
\mathrm{kg} \mathrm{ha}^{-1}\end{array}$ & $\begin{array}{l}\mathrm{N} \text { content } \\
\mathrm{g} \mathrm{kg}^{-1}\end{array}$ & $\begin{array}{l}\text { N yield } \\
\mathrm{kg} \mathrm{ha}^{-1}\end{array}$ & $\begin{array}{l}\mathrm{N} \text { content } \\
\mathrm{g} \mathrm{kg}^{-1}\end{array}$ & $\begin{array}{l}\text { N yield } \\
\mathrm{kg} \mathrm{ha}^{-1}\end{array}$ \\
\hline \multicolumn{7}{|l|}{ Grass (450 kg Nha $\left.\mathrm{kg}^{-1}\right)$} \\
\hline G3 & 21.7 & 430 & 27.9 & 452 & 32.9 & 442 \\
\hline G2 & & & 24.8 & 415 & 29.7 & 413 \\
\hline G1 & & & & & 26.5 & 420 \\
\hline \multicolumn{7}{|l|}{ Lucerne $\left(0 \mathrm{~kg} \mathrm{Nha^{-1 } )}\right.$} \\
\hline $\mathrm{L} 3$ & 29.3 & 392 & 31.4 & 503 & 29.8 & 513 \\
\hline $\mathrm{L} 2$ & & & 32.3 & 439 & 29.9 & 511 \\
\hline L1 & & & & & 31.8 & 577 \\
\hline \multicolumn{7}{|l|}{ Maize $\left(225 \mathrm{~kg} \mathrm{~N} \mathrm{ha} \mathrm{C}^{-1}\right)$} \\
\hline M1-3 & 13.8 & 188 & 13.4 & 217 & 12.9 & 220 \\
\hline
\end{tabular}

(Table 1). Nitrogen yields of grass ranged from 413 to $452 \mathrm{~kg} \mathrm{ha}^{-1}$, of lucerne from 392 to $577 \mathrm{~kg} \mathrm{ha}^{-1}$ and of maize from 188 to $220 \mathrm{~kg} \mathrm{ha}^{-1}$. Crop age had hardly any effect; in 1981 the second-year crops of grass and lucerne were slightly superior to the first-year crops.

Generally, the nitrogen yields of all plots were quite high and the yields of lucerne were somewhat higher than those of grass, except for those in 1980. Within a growing season the nitrogen yields per cut of lucerne declined with successive cuts. Taking into account the number of growing-days, the rate of nitrogen uptake decreased with each successive cut; from about $5 \mathrm{~kg} \mathrm{ha}^{-1} \mathrm{~d}^{-1}$ with the first cut to about $1 \mathrm{~kg} \mathrm{ha}^{-1} \mathrm{~d}^{-1}$ with the last cut.

Nitrogen yields of maize were about half of those of grass and lucerne. The main cause was the low nitrogen content of maize at harvest-time; on an average the nitrogen content of the whole plant was $13.3 \mathrm{~g} \mathrm{~kg}^{-1}$ compared with about $28.0 \mathrm{~g} \mathrm{~kg}^{-1}$ for optimally fertilized perennial ryegrass and about $30.0 \mathrm{~g} \mathrm{~kg}^{-1}$ for lucerne.

\section{Interrelations between dry-matter and nitrogen yields}

All crops, within the three cropping sequences, were grown at four nitrogen levels in 1982. Hence, the yield data of first-year grass (G1), lucerne (L1) and maize (M1) in 1982 are presented in Fig. 1 for a comparison of the nitrogen use of grass, lucerne and maize. This comparison includes the response of dry matter yield to nitrogen dressing (quadrant I), of dry matter yield to nitrogen yield (quadrant II), and of nitrogen yield to nitrogen dressing (quadrant III). This figure is based on the procedure of Frankena \& de Wit (1958). The dotted lines in quadrant II represent the fraction of nitrogen in the dry matter.

Maximum nitrogen yields differed widely between the three crops (see Fig. 1, quadrant II), although average maximum dry matter yields varied only between 15 and 19 tonnes per ha. This pattern is mainly caused by a large difference in nitrogen 


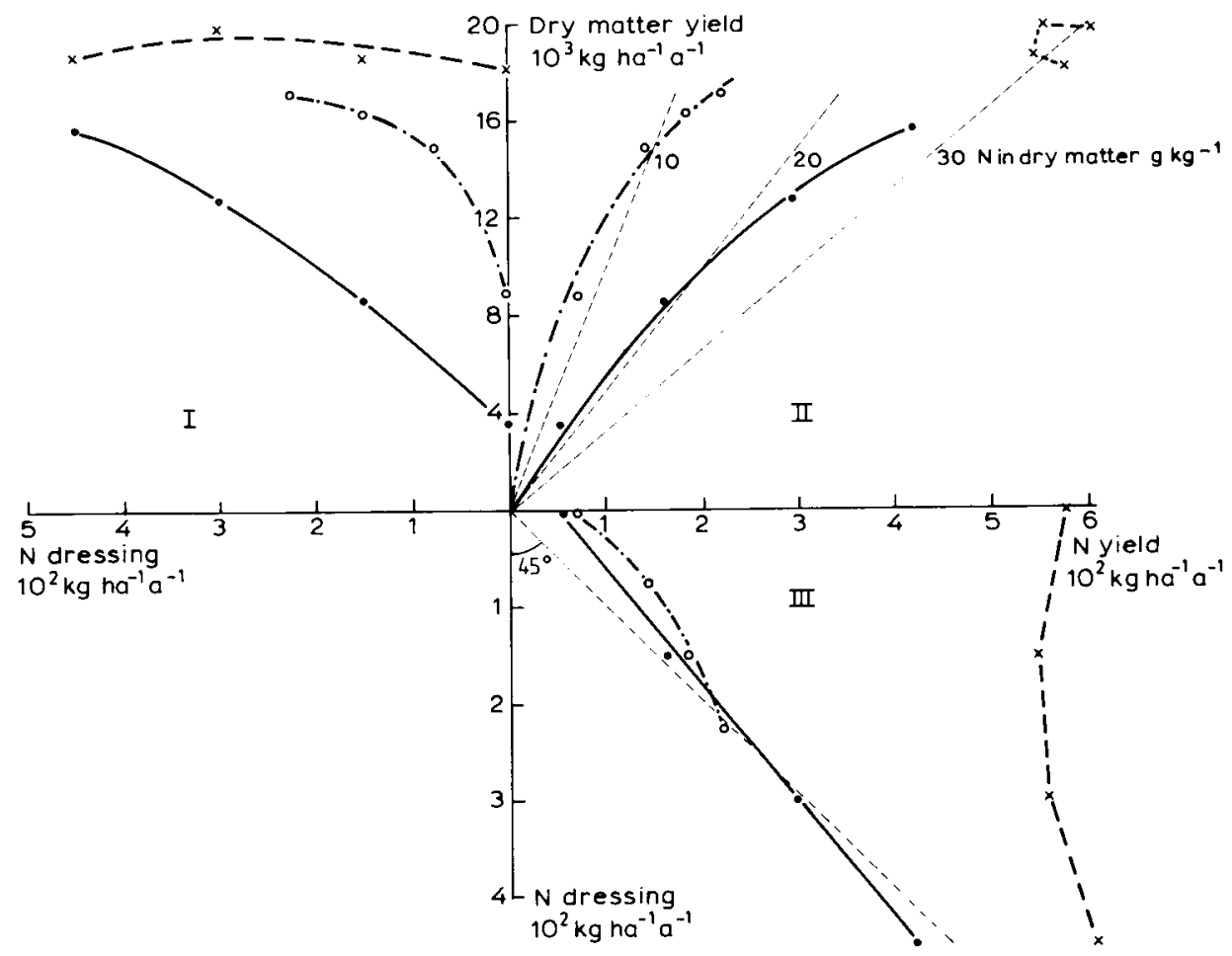

Fig. 1. Relationships between annual $\mathrm{N}$ dressing and dry matter yield of first-year grass $(-0)$, of firstyear lucerne $(\mathrm{x}-\mathrm{-x})$ and of maize $(\mathrm{O}-\ldots .-\mathrm{O})$ in 1982 in quadrant $\mathrm{I}$; between $\mathrm{N}$ yield and dry matter yield in quadrant II and between annual $\mathrm{N}$ dressing and $\mathrm{N}$ yield in quadrant III.

content of the harvested produce. With grass and lucerne the nitrogen content varied between the successive cuts within a season.

The response of dry matter yield to nitrogen dressings after the preceding crop spring wheat is shown in quadrant I (Fig. 1). These curves distinctly show that lucerne hardly responded to nitrogen fertilizer; grass, however, showed a great response in the whole range from 0 to $450 \mathrm{~kg} \mathrm{ha}^{-1}$; whereas maize only responded at lower nitrogen dressings. The maize crop produced $9 \mathrm{t}$ of dry matter without nitrogen dressing; without nitrogen fertilizer grass yielded about $3.5 \mathrm{t}$ DM per ha.

The low nitrogen yields of grass and maize without nitrogen fertilizer (quadrant III) indicate the very low mineralization rate of this soil, due to a low organic matter content. The equilibrium between nitrogen input and output with grass was $300 \mathrm{~kg}$ $\mathrm{ha}^{-1}$. Several authors (e.g. Frankena \& de Wit, 1958; Alberda, 1972; Sibma \& Alberda, 1980) reported an equilibrium at a $\mathrm{N}$ level of about $400 \mathrm{~kg} \mathrm{ha}^{-1}$ under other conditions.

Quadrant III (Fig. 1) shows that the nitrogen recovery of the applied fertilizer by maize and grass was about the same. The nitrogen yield of grass and maize without nitrogen dressing was 50 and $70 \mathrm{~kg} \mathrm{ha}^{-1}$, respectively. The nitrogen yield of lucerne 
was $575 \mathrm{~kg} \mathrm{ha}^{-1}$ and hardly showed any response to nitrogen dressings. With a nitrogen dressing of $450 \mathrm{~kg} \mathrm{ha}^{-1}$ the nitrogen yield of lucerne rose to $600 \mathrm{~kg} \mathrm{ha}^{-1}$. So nitrogen fixation was much reduced by the nitrogen dressing, assuming that the soil nitrogen reserves were the same.

\section{Estimates of nitrogen fixation by lucerne}

Estimates of nitrogen fixation by legume crops may be based on total $\mathrm{N}$ accumulation of the crops, on long-term nitrogen balance studies with lysimeters or on more direct measurements such as the acetylene reduction assay of nitrogenase activity and the isotope dilution method (La Rue \& Patterson, 1981; Heichel et al., 1981). In our experiments we used a procedure to adjust the measure of apparent $\mathrm{N}$ fixation by the nitrogen accumulation of the above-ground parts of the crop with a correction for the contribution of soil $\mathrm{N}$ and for the change in mineral soil $\mathrm{N}$ reserves. The contribution of soil $\mathrm{N}$ was obtained by growing maize and grass as non-fixing crops in comparison with lucerne - the so-called difference method (Williams et al., 1977). The difference in $\mathrm{N}$ yield between lucerne and grass was affected by the amount of $\mathrm{N}$ fertilizer (Table 2). Assuming that lucerne and grass take up soil $\mathrm{N}$ in proportion to the amount available, and differences caused by growth patterns and root morphology are small, we can assess the amount of nitrogen fixation on the unfertilized plots. Allowing for minor changes in mineral soil $\mathrm{N}$ reserve, the calculated nitrogen fixation by rhizobia, in symbiosis with lucerne, ranged from 462 to $507 \mathrm{~kg}$ $\mathrm{ha}^{-1}$ in 1982 for a third-year and first-year crop, respectively. If we also assume that mineral soil $\mathrm{N}$ is taken up preferentially by lucerne, the apparent $\mathrm{N}$ fixation with

Table 2. $\mathrm{N}$ yields of lucerne and grass, the change in mineral soil nitrogen reserves and the calculated $\mathrm{N}$ fixation in $\mathrm{kg} \mathrm{ha}^{-1}$.

\begin{tabular}{|c|c|c|c|c|c|c|}
\hline \multirow[t]{2}{*}{ Crop } & \multirow{2}{*}{$\begin{array}{l}\text { N supply } \\
\left(\mathrm{kg} \mathrm{ha}^{-1} \mathrm{a}^{-1}\right)\end{array}$} & \multicolumn{3}{|c|}{$\mathrm{N}$ yield $\left(\mathrm{kg} \mathrm{ha}^{-1} \mathrm{a}^{-1}\right)$} & \multirow{2}{*}{$\begin{array}{l}\text { N mineral change* } \\
\left(\mathrm{kg} \mathrm{ha}^{-1} \mathrm{a}^{-1}\right)\end{array}$} & \multirow{2}{*}{$\begin{array}{l}N \text { fixation } \\
\left(\mathrm{kg} \mathrm{ha}^{-1} \mathrm{a}^{-1}\right)\end{array}$} \\
\hline & & $\begin{array}{l}\text { lucerne } \\
\text { (L) }\end{array}$ & $\begin{array}{l}\text { grass } \\
(\mathrm{G})\end{array}$ & $\mathrm{L}-\mathrm{G}$ & & \\
\hline \multirow[t]{4}{*}{ L3, G3 } & 0 & 513 & 60 & 453 & +9 & 462 \\
\hline & 150 & 526 & 178 & 348 & -2 & 346 \\
\hline & 300 & 556 & 320 & 236 & -14 & 222 \\
\hline & 450 & 575 & 442 & 133 & -26 & 107 \\
\hline \multirow[t]{4}{*}{$\mathrm{L} 2, \mathrm{G} 2$} & 0 & 511 & 56 & 455 & +18 & 473 \\
\hline & 150 & 532 & 153 & 379 & +16 & 395 \\
\hline & 300 & 550 & 289 & 261 & +23 & 284 \\
\hline & 450 & 563 & 413 & 150 & +11 & 161 \\
\hline \multirow[t]{4}{*}{$\mathrm{L} 1, \mathrm{G} 1$} & 0 & 577 & 57 & 520 & -13 & 507 \\
\hline & 150 & 544 & 161 & 383 & -3 & 380 \\
\hline & 300 & 556 & 294 & 262 & +4 & 266 \\
\hline & 450 & 604 & 420 & 184 & +11 & 195 \\
\hline
\end{tabular}

* Difference in $\mathrm{N}$ mineral change between lucerne and grass is calculated as follows: [NsL - NaL] [NsG - NaG], where: $\mathrm{Ns}$ and $\mathrm{Na}=$ inorganic soil $\mathrm{N}$ in spring and autumn, and $\mathrm{L}$ and $\mathrm{G}=$ lucerne and grass, respectively. 
higher nitrogen input can be assessed. Nitrogen contribution by fixation dropped to $107-195 \mathrm{~kg} \mathrm{ha}^{-1}$ with $\mathrm{N}$ dressings up to $450 \mathrm{~kg} \mathrm{ha}^{-1}$.

The fraction of nitrogen yield of lucerne attributed to nitrogen fixation ranged from 0.93 to 0.19 depending on the amount of nitrogen applied to the crop. Crop age had only minor effects on nitrogen yield and nitrogen fixation rates.

\section{Soil nitrogen reserves}

The pattern of changes in mineral soil $\mathrm{N}$ under grass, lucerne and maize are shown in Fig. 2 for the period from autumn 1982 to autumn 1983. Soil $\mathrm{N}$ reserves were low after harvesting the main crop in autumn. On the plots without nitrogen fertilizer these reserves were 7,21 and $18 \mathrm{~kg} \mathrm{ha}^{-1}$ for grass, lucerne and maize, respectively; at high levels of nitrogen input reserves for grass were $76.5 \mathrm{~kg} \mathrm{ha}^{-1}$.

After winter mineral $\mathrm{N}$ reserves were assessed on 10 June, before the following crop, maize, started to grow. Because of the rainfall in winter and the wet spring a high proportion of the soil $\mathrm{N}$ reserve was stored in the soil layers at $40-60 \mathrm{~cm}$ depth. Evidently mineral nitrogen reserves stored in the deeper soil layers and nitrogen

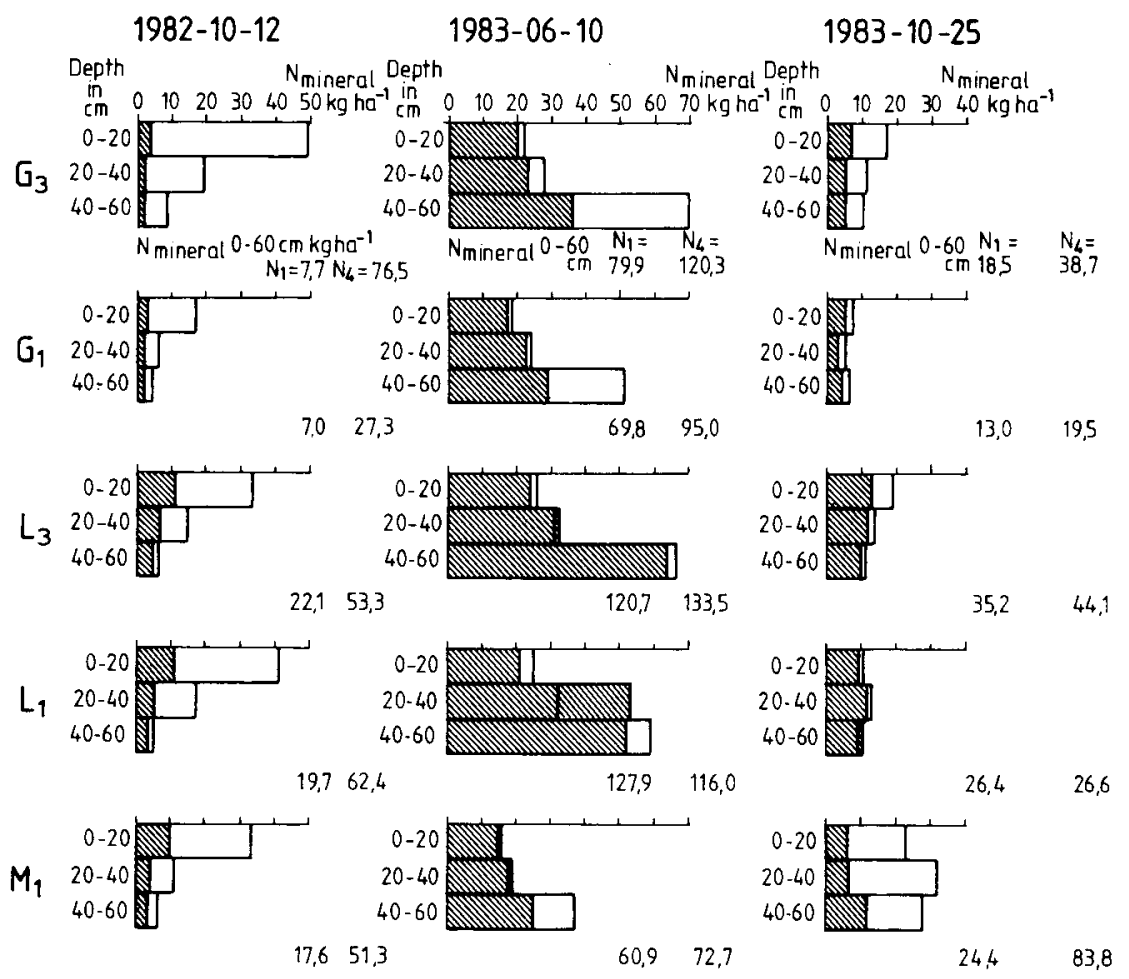

Fig. 2. The $\mathrm{N}$ mineral content in layers of $20 \mathrm{~cm}$ to $60 \mathrm{~cm}$ depth after 3 - and 1 -year grass $(\mathrm{G} 3, \mathrm{G} 1)$ and lucerne (L3, L1) and after maize, wheat, maize (M1) on 12 October 1982 and 10 June 1983 and after the testcrop maize on 25 October 1983. Open bars: high N supply; hatched bars: no N supply in the preceding years. 
losses by leaching and denitrification could not be taken into account. The presented data indicate clear differences in amounts of residual nitrogen available to the following maize crop. After a preceding crop of grass, lucerne and maize mineral soil $\mathrm{N}$ reserves were about 75,125 and $60 \mathrm{~kg} \mathrm{ha}^{-1}$, respectively, on the unfertilized plots and about 110,125 and $70 \mathrm{~kg} \mathrm{ha}^{-1}$ on the plots with a high nitrogen dressing in the previous year.

Mineral soil $\mathrm{N}$ reserves were determined again at the end of October after harvesting the maize crop. In all the plots $\mathrm{N}$ reserves were less than $45 \mathrm{~kg} \mathrm{ha}^{-1}$ in a soil layer of $60 \mathrm{~cm}$ depth, except for plot M1 with a high nitrogen dressing to the crop in 1983. It may be concluded that mineral $\mathrm{N}$ reserves in the soil after lucerne were equal to or even somewhat higher than those after grass fertilized with $450 \mathrm{~kg} \mathrm{~N}$ $\mathrm{ha}^{-1}$ year $^{-1}$. However, in all plots the residual amounts of mineral nitrogen were relatively low, when compared with the nitrogen yield of the crop.

Residual effects of the various cropping systems on dry matter and nitrogen yields of maize

In 1983 a maize crop was grown to assess the after-effects of 1-, 2- or 3-year cropping of grass, lucerne and maize on the yield of a subsequent crop. This after-effect may be subdivided into a nitrogen effect and a residual effect of all other factors involved. To determine the nitrogen effect, the response of the maize crop to nitrogen was determined in 1983 at four levels of nitrogen fertilizer (see Fig. 3). The yield level of maize was relatively low for all treatments, because of the extremely late sowing data, 6 June; the growing season was shortened to 140 days.

The curves in Fig. 4a-c show that dry matter yields of maize with lucerne as a preceding crop were independent of the nitrogen fertilizer regime and as high as those

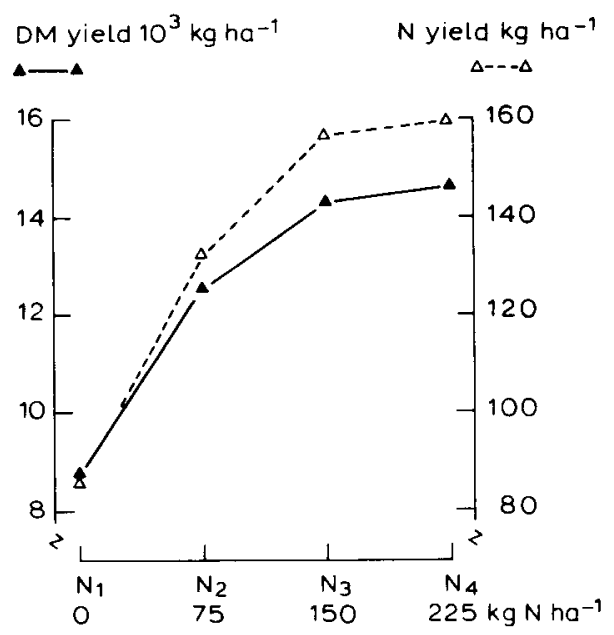

Fig. 3. Dry matter and nitrogen yields of the testcrop maize (M1) in 1983 after $\mathrm{N}$ dressings of $0,75,150$ and $225 \mathrm{~kg} \mathrm{ha}^{-1}$. 

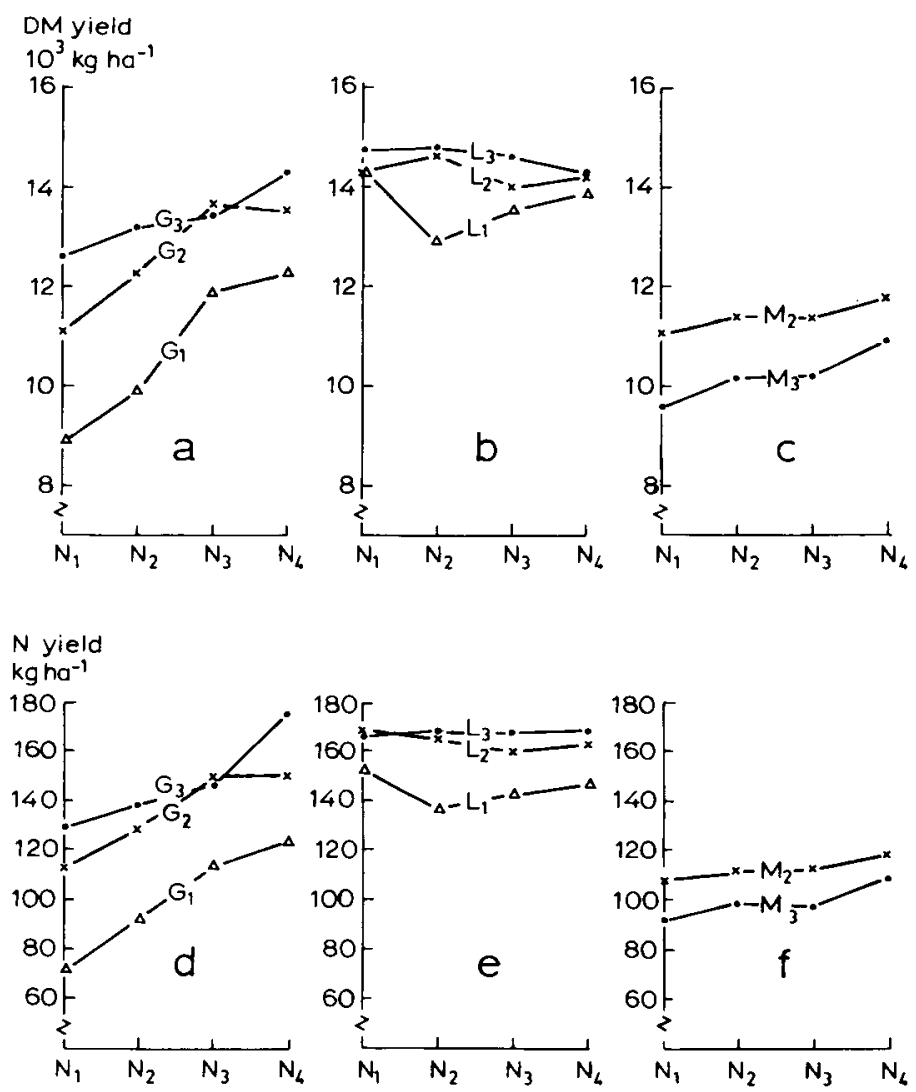

Fig. 4. Dry matter (a, b, c) and nitrogen (d, e, f) yields of the test crop maize in 1983 without $N$ dressings; the preceding crops are the following: a and d: grass (G3, G2 and G1) at four nitrogen levels $b$ and e: lucerne (L3, L2 and L1) at four N levels

$\mathrm{c}$ and $\mathrm{f}$ : (lucerne/grass)-maize-maize (M3); wheat-(lucerne/grass)-maize (M2).

fertilized in 1983 with $225 \mathrm{~kg} \mathrm{ha}^{-1}$ year $^{-1}$ (see Fig. 3). With grass as a preceding crop only the plots with a $\mathrm{N}$ dressing of $450 \mathrm{~kg} \mathrm{ha}^{-1}$ annually attained a comparable yield level. The age of the preceding crop was more important with grass than with lucerne. The difference between one year and two years of maize as a preceding crop may be explained by the nitrogen contribution of the grass/legume mixture grown in 1981 and in 1980, respectively. Fig. 4a-c shows that the residual effect of maize as a preceding crop is less than of lucerne or well-fertilized grass. However, after one year grass without $\mathrm{N}$ fertilizer less nitrogen was available to the following crop than after a maize crop. As a consequence dry matter yields of the following crop were reduced.

The residual effects of the preceding crop on the nitrogen yields of maize are even more striking (Fig. 4d-f). A second- and third-year lucerne crop shows a resid- 
ual nitrogen yield of about $170 \mathrm{~kg} \mathrm{ha}^{-1}$; a first-year lucerne crop gave a residual nitrogen yield equal to a $\mathrm{N}$ supply of $150 \mathrm{~kg} \mathrm{ha}^{-1}$ year $^{-1}$ in 1983 (see Fig. 3). After 1,2 or 3 years of grass, with an annual nitrogen dressing of $450 \mathrm{~kg} \mathrm{ha}^{-1}$, the nitrogen yield was about 120,150 and $170 \mathrm{~kg} \mathrm{ha}^{-1}$. Nitrogen dressings of $450 \mathrm{~kg} \mathrm{ha}^{-1}$ to a preceding grass crop resulted in an additional nitrogen yield of $40-50 \mathrm{~kg} \mathrm{ha}^{-1}$ in the subsequent maize crop, when compared to unfertilized grass. The nitrogen mineralization of a three-year grass crop outyielded a first-year grass crop with about $50-60 \mathrm{~kg}$ $\mathrm{ha}^{-1}$.

\section{Discussion}

Data on dry matter and nitrogen yields of the three crops and on nitrogen fixation of lucerne are to some extent affected by the growing conditions of 1982 . The relatively bright and dry summer favoured growth and yield of lucerne and maize, but depressed the growth of grass during August and early September. However, this yield depression was compensated by a higher yield of the last cut on 5 October. Early growth of 2nd- and 3rd-year grass in the spring of 1982 was delayed by frost damage; the growth pattern of the first-year grass crop was comparable to that in the previous years. Therefore, the yield data of this crop are presented in Fig. 1 and used in assessing nitrogen fixation of lucerne with a reference crop.

The nitrogen yields of lucerne in 1982 exceeded those of grass with about $150 \mathrm{~kg}$ $\mathrm{ha}^{-1}$; this difference in 1981 only was 25 to $50 \mathrm{~kg} \mathrm{ha}^{-1}$. However, in 1980 the nitrogen yield of lucerne was less than that of grass, due to an exceptionally low dry matter yield of lucerne. The effect of nitrogen dressings on dry matter and nitrogen yield of grass was great in 1982; the data presented in Fig. 1 and table 2 even show that the maximum yield was not attained with a nitrogen dressing of $450 \mathrm{~kg} \mathrm{ha}^{-1}$. The main reason for this high yield response to nitrogen, on the one side was the low nitrogen supply by mineralization of soil nitrogen reserves and on the other the high nitrogen recovery; on an average about 0.80 for $\mathrm{G} 1, \mathrm{G} 2$ and $\mathrm{G} 3$ (see Fig. 1, quadrant III). There was a slight positive effect of nitrogen dressings on the nitrogen yield of 2- and 3-year lucerne in 1982 of about $60 \mathrm{~kg} \mathrm{ha}^{-1}$ (see Table 2). This trend was absent in the first-year lucerne crop. This crop might profit from residual nitrogen of the preceding crop.

Estimates of nitrogen fixation based on above-ground nitrogen yields, ranged from 107 to $507 \mathrm{~kg} \mathrm{ha}^{-1}$ depending on the $\mathrm{N}$ supply and the age of the lucerne and grass crops. The reference method used in assessing apparent nitrogen fixation of lucerne may slightly overestimate the true fixation rate, because of deeper rooting of lucerne compared with grass and therefore the ability to extract more $\mathrm{N}$ from mineral soil reserves. However, the accumulation of nitrogen fixed in roots and stubbles was not taken into account. From the annual increase in dry weight and the nitrogen after-effect net accumulation of nitrogen in roots and stubbles may be estimated at about 50,25 and $0 \mathrm{~kg} \mathrm{ha}^{-1}$ year $^{-1}$ for a first-, second- and third-year lucerne crop, respectively. For a realistic comparison of estimates of nitrogen fixation by forage crops, the length of the growing season and the total dry matter yield have to be considered (Heichel et al., 1981). For a full 12-month growing season ex- 
tremely high rates of nitrogen fixation have been reported; $406-681 \mathrm{~kg} \mathrm{ha}^{-1}$ for white clover in New Zealand (Sears et al., 1965) and of about $1000 \mathrm{~kg} \mathrm{ha}^{-1}$ for lucerne in Peru (Versteeg et al., 1982). The length of the growing season of lucerne in the Netherlands is about 6 months; from mid-April to mid-October. A first-year crop may take some advantage of growth in the preceding year, when the crop is sown at the end of July or early August. Under favourable conditions autumn growth may contribute $50-60 \mathrm{~kg} \mathrm{ha}^{-1}$ to the nitrogen yield of a 'first'-year lucerne crop.

Determinations of mineral soil $\mathrm{N}$ reserves in spring and autumn showed that a grass and lucerne crop at low nitrogen dressings deplete soil nitrogen reserves during the growing season and only enhance the mineral soil $\mathrm{N}$ reserves with $\mathrm{N}$ dressings of more than $300 \mathrm{~kg} \mathrm{ha}^{-1}$ on this soil type. The assessments of soil nitrogen reserves were also used in determining the nitrogen after-effects of the previous cropping system. Comparing the mineral nitrogen reserves assessed on 10 June in 1983, with the nitrogen yield of the test-crop maize, on an average nitrogen yields ranged from 0.9 to 1.9 times the mineral soil $\mathrm{N}$ reserves present on the sowing date of the test crop. Striking is that the nitrogen after-effect of 2- and 3-year grass without $\mathbf{N}$ fertilizer amounted to 115 and $130 \mathrm{~kg} \mathrm{ha}^{-1}$, respectively and after maize $90 \mathrm{~kg} \mathrm{ha}^{-1}$. So, the unfertilized 2- and 3-year grass crop enhanced the mineralization of nitrogen from the soil organic material with about $25-40 \mathrm{~kg} \mathrm{ha}^{-1}$. This was not the case for the first-year grass crop; the nitrogen after-effect was only $75 \mathrm{~kg} \mathrm{ha}^{-1}$.

From this four-year experiment it may be concluded that an annual nitrogen input of about $450 \mathrm{~kg} \mathrm{ha}^{-1}$ was needed for a high dry matter yield of grass. The nitrogen recovery of fertilizer $\mathrm{N}$ amounted to about 0.80 with a grass crop. With a lucerne crop the same dry matter yields and even higher nitrogen yields could be attained without $\mathrm{N}$ dressings. The yields of a first-, second- and third-year crop did not differ significantly.

Soil nitrogen residues in autumn were higher after a highly fertilized grass crop than after lucerne grown without nitrogen fertilizer. The after-effects of fertilized grass and unfertilized lucerne on a maize crop were of the same order.

Without considering cultivation and conservation problems, lucerne has the potential to yield the same amount of dry matter and protein as grass. The main difference is the need for a high nitrogen input with grass and no need at all with lucerne grown on a suitable soil. This saving of nitrogen is worth paying attention to in cropping systems with forage crops.

\section{References}

Alberda, Th., 1972. Nitrogen fertilization of grassland and the quality of surface water. Dutch Nitrogen Fertilizer Review 15: 45-51.

Burg, P. F. J. van, M. L. 't Hart \& H. Thomas, 1980. Nitrogen and grassland; past and present situation in the Netherlands. In: W. H. Prins \& G. H. Arnold (Eds), The role of nitrogen in intensive grassland production, p. 15-34. Pudoc, Wageningen.

Frankena, H. J. \& C. T. de Wit, 1958. Stikstofopname en grasgroei. Landbouwkundig Tijdschrift 70: 465-472.

Heichel, G. H., D. K. Barnes \& C. P. Vance, 1981. Nitrogen fixation by forage legumes and benefits to 
the cropping system. Proceedings 6th Annual Symposium, Minnesota Forage and Grassland Council (St. Paul, MN).

La Rue, F. A. \& T. G. Patterson, 1981. How much nitrogen do legumes fix? Advances in Agronomy 34: 15-38.

Meer, H. G. van der, 1982. Effective use of nitrogen on grassland farms. In: A. J. Corrall (Ed.), Efficient grassland farming. Proceedings 9th General Meeting of the European Grassland Federation. Occasional Symposium No 14, British Grassland Society, p. 61-68.

Sears, P. D., V. C. Goodall, R. H. Jackman \& G. S. Robinson, 1965. Pasture growth and soil fertility. VIII. The influence of grasses, white clover, fertilizers and the return of herbage clippings on pasture production of an impoverished soil. New Zealand Journal of Agricultural Research 8: 270-283.

Sibma, L. \& Th. Alberda, 1980. The effect of cutting frequency and nitrogen fertilizer rate on dry matter production, nitrogen uptake and herbage nitrate content. Netherlands Journal of Agricultural Science 28: $243-251$.

Sibma, L. \& J. H. J. Spiertz, 1986. Dry matter production and nitrogen utilization in cropping systems with grass, lucerne and maize. 1. Comparison of crop characteristics, growth and production. Netherlands Journal of Agricultural Science 34: 25-35.

Versteeg, M. N., I. Zippori, J. Medina \& H. Valdevia, 1982. Potential growth of alfalfa (Medicago sati$v a \mathrm{~L}$.) in the desert of Southern Peru and its response to high NPK-fertilization. Plant and Soil 67: 157165.

Williams, W. A., M. B. Jones \& C. C. Dehriche, 1977. Clover N-fixation measurements by total N-difference and N A-values in lysimeters. Agronomy Journal 69: 1023-1024. 